\title{
Listening to Spirituality: The Cultural Significance of Chinese Christian Literature--Taking Shi Wei's literary and artistic creation as the center
}

\author{
Chongguang Zhai \\ No. 510632, West 601, Whampoa Avenue, Guangdong, Jinan University, 6818 \\ 550377793@qq.com
}

Keywords: Chinese literature; spiritual literature; Shi Wei

\begin{abstract}
The cross regional and cross-cultural literary writing of 'New Immigrant Literature' is presently a noticeable literary phenomenon. The concepts of spiritual literature explicitly put forward by writer Shi Wei and his literary and artistic practices have had a wide influence. "Spiritual literature creation", has deep cultural significance for the cultural dimensions of enlightenment in the experience of Chinese writers. The process of exchanges between Western and Chinese traditional culture are listening, and it is becoming a bridge between the two.

The relationship between religion and literature has a long history. Since modern times, Christian culture has had a great influence on Chinese modern literature. During this new period, some representative writers, such as Bei Cun、Shi Wei, have appeared.
\end{abstract}

\section{The manifestation of spiritual writing}

Shi Wei is a relatively active overseas Chinese writer who has some influence both inside and outside of China. In the 1980s created a large number of poems, in 'people's Literature', "poetry", 'star poetry' and other newspapers across the country published 200 poems, she also wrote a novel "Boneless" (written, published in 1997, Inner Mongolia People's Publishing House). In the 1990s, women's writing formed a new dimension that was entirely different from the new literary tradition of the modern century. Some scholars believe that one of the most striking features of female writing in the 90s is that is full of gender awareness and gender consciousness. This new dimension is a tendency to emphasize women's own characteristics and to personalize them more. The contemporary female writer Shi Wei before leaving China her work was characterized by attention to modern Chinese life, tracing the awakening of women's consciousness, and this is when Chen Ran, Lin Bai and other female writers are comparable.

By the end of 1996, Shi Wei moved to the United States, especially in the 1999 Letter to Faith, great changes had taken place in her writing, she said: "a Christian writer should have an innate mission, in theory and practice to transfer the biblical revelation, the light of the world view and value the concept of architecture, the text to manifest God as" letter "[1] the spirit of life." She has twice had to rewrite the domestic publication of the novel "Boneless" (1997 edition, Inner Mongolia people's Publishing House), the rewritten novels are called "Tenderness" (revised June 2002 edition, published in 2003, Chinese film press), "Family" Mei Juan (January 2013 three Edition Revised Edition 2013 Kyushu, press), the novel's title and the cover have changed greatly, and the author writing content can feel a change, and the "spirit" of the show. In this novel the author of each edition was revised and modified, I think she added more to the novel, mainly to increase the

[1] Shi Wei "' Divine Writing "The Call of God", "Shi Wei Song Song",Zhuhai press, 2009 edition, page 356th,. 
contents of two aspects: one is the spiritual dimension of transcendence, and one is to add to the meaning of original sin. In these two aspects, we can see that Shi Wei was influenced by Christian culture. The overseas release for this novel the first time saw more added to the introduction the protagonist Lu Wenyin wrote about encountering snow at the age of thirteen, the snow was so cold "to wake up hungry" in her soul, at the same time in the snow she saw her first man, "she is facing the world, facing the fate, but also facing the curse of an eternal existing.", "the hunger of the soul" is reminiscent of existing dimensions beyond people, "the ancient curse" was also placed "the Bible Genesis" in the records of human ancestor, sin, is to eat the forbidden fruit in the garden of Eden metaphor. In the text of its revised version, a number of such passages have been added:

"And after the integration, they will find that the other side is really their share of desire?" Still disappointed? Still hungry?"

"When he looked into the sky through the woman's body with his eyes open, he could not help asking the God who made everything:" is this the woman you have made? Is this the bisexual love you have constructed?"

"On the face of it, fate and the environment will pollute him again and again, but in fact, the evil of man is repeatedly dirty and laughs at the longing for beauty and purity in her mind."

The first two paragraphs show the transcendental soul dimension, and the third paragraph expresses the consciousness of original sin. From this, we can see the novel rewritten by the author and increase the aesthetic sense of spirituality. Shi Wei's creation is the change from "soul" to the creation of a "spiritual" creative transformation, Shi Wei talked about writing "Boneless", " in the novel soul I said "I uphold the core values of truth, and strive to free women, so there is no hypocrisy present, in war, the reform period, the survival plight and the physical and spiritual struggle." ${ }^{[2]}$ Through the above analysis we can see that, the modified novels on Chinese traditional narrative "the soul" is really an artistic conception foundation, and increase the implication of the "spiritual" divine truth. Shi Wei's "spiritual literature writing", is the expatriate received belief, due to these changes in literary creation, we can see this in Chinese and Christian cultural blend in writing of other overseas Chinese writers such as Li Yan and Zhang Ling and other new immigrants writers. However, Shi Wei explicitly put forward the concept of spiritual literature, which in itself is the practice of the concept of spiritual literature. In the domestic market and the creation of "Soft Without Bone" focusing on the awakening of women in the novel, the revised work has more religious consciousness and human consciousness, this is when Shi Wei moved overseas and the creation of commonness and individuality was found in her work.

With this publication, most of the attention was on women's survival and family beauty in Shi Wei work, after the publication of "Exile Paradise" and "Redwall Magnolia" two novels focused spiritual life and the emotional life of contemporary Chinese after the reform and opening up period. These two works have more biblical elements in the form of texts, and they also pay more attention to the spiritual existence of human beings. They also add to the spiritual dimension of writing. In the writing of "Redwall Magnolia", Shi Wei studied Theology and psychology, the novel text also tries to protect and cure readers with heart trauma, which is a feature of this novel. Such writing attempts were not mentioned in previous Chinese, Christian literature, or spiritual literature. "Beauty" of the family narrative of hundred years of modern Chinese "family" in the four generation of women, Shi Wei last year wrote an across the centuries of modern history fiction, but this novel material and spirit and the "family" beauty is completely different. Shi Wei in 2016

[2] Shi Wei: "From" Soul "to" Spiritual "-- Exploration of Novel Creation." Mr. Shi sent to the author of the article. 
published by the Chinese Christian Church History Novel "Apostate", describes the Chinese Christians living through social change in contemporary Chinese. It had a "positive perspective", and expanded the Chinese Christian literature theme; it was hailed by modern literary critic Chen Ruilin as "Of the sky". "Renegades" and "Beauty" are the same family, recording Chinese in a modern and contemporary history of the life, only with "several gentle female narratives" in the family of beauty, in worldly desires, and the struggle. "The apostate" recorded a few more "spiritual" of Chinese Christian life, although they are also guilty with prints and possible human limitations, the author describes the modern China Christian spirit within the flesh and the reality of struggle, growth and staying true to the Lord of life. The sound as the prototype of the demolition works, recorded China's modern "local church" there it can be said that so far, Shi Wei is the most important in spiritual literature work.

\section{Listening dialogue and cultural blending}

In recent years, overseas Chinese writer Shi Wei's Spiritual Bible based on the systematic theology theory of human beings has also received extensive attention. In 2008, the Symposium on Chinese spiritual literature was held at Shanghai Normal University. In 2009, a conference paper entitled "Soul Salvation and Spiritual Literature" was published. For 'spiritual literature' in domestic literary and cultural circles, some critics have noted that 'spiritual literature" for Chinese cultural compensation has a divine meaning, for example, Tang Xiaolin believed that in 'Modern Chinese Literature' spiritual writing is the breakthrough bound and in 'literary talk' the transcendental deserves close attention ${ }^{[3]}$. It is perhaps more accurate to say 'how literature can listen to the transcendental world' with saying 'how literature speaks to the transcendental world', because speech can only begin with better listening. Since modern times, China has been forced to listen to 'others' in the west. A Chinese pioneer of modern literature Lu Xun has a rational center with Confucius to replace the etiquette center and a new philosophy 'by foreigners to expel the ancient saints', Lu Xun put forward that is was just a culture of 'foreign students' and a 'hearing error', he put forward 'national prosperity' rather than rational truth as the goals of enlightenment.

The feelings of the Chinese nation has been the concern of Chinese intellectuals in particular the future of the nation and the country, and rational enlightenment has always been the pursuit of modern Chinese intellectuals, along with the basic content of the Enlightenment of modern Chinese literature. In his essay "the transformation of misery into words, why weightlessness", Zhang Zhiyang reflected that the upper limit of Chinese culture is 'country' and the lower limit is 'home', which has neither transcendental divinity nor individual soul. Today's literature, not only in the face of secular theocracy, is also facing the secular human excessive release of poignant reality. As both emotional, rational, divine and unique existence, only emphasizes the aesthetic of rational enlightenment, the individual 'divinity' soul may be ignored, and can achieve complete enlightenment, and cannot make a complete 'person' stand up. In this case, "open our senses, open to the world, learn to listen to voices from the depths of life and the furthest reaches of the universe, and have the courage and the ability to say everything. Only in this way can we really have the world and truly have our own lives." ${ }^{[4]}$ "Listen to the transcendental world" spiritual literature creation, is an open creation, letting Chinese literature have the sacred value of listening, transcendence may be more concerned about human nature, paying attention to individual human

[3] Tang Xiaolin: Facing the Soul Itself - Modern Chinese Religious Poetics, Chinese Social Sciences Press, 2016 Edition,page 248-249

${ }^{[4]}$ Zhang Hong: the Poetics of sound - A Study of Lyric Art in Modern Chinese Poetry. Shanghai Book Store press, 2016 edition, page 190 
dignity, to open the individual soul dimensions, this is a trend in Chinese literature.

Of course, this kind of writing is tough. Yu Hong commenting on his images, "the light penetration that can hear the divine summons in the soul, walking meditation and understanding of Enlightenment of history, and in China, such people are rare, because people's ears are in a sacred gap (In modern history the legitimacy of colonial culture strengthened the vacancy). ${ }^{[5]}$ On Chinese literary creation, one of the few Shi Wei's 'spiritual literature' is 'to listen sacred', her divinity writing is "sitting to hear God's feet, is nestled in his arms singing" "6]. Shi Wei's 'spiritual literature writing', is the expatriate received belief of changes in literary creation. This cultural blend can be seen in the work of overseas writers like like Li Yan and Zhang Ling and other new immigrants writers. However, Shi Wei explicitly put forward the concept of spiritual literature, and he himself is a practitioner of its concepts. Domestically with the creation of "soft without bone focus on women's awakening" of the novel, compared to its release in China in the new century the revised version has more religious and human consciousness, this is when Chinese writer Shi Wei moved overseas after the creation of the commonness and individuality. After converting to the Christian faith, the writing was very different to previous work. With the opening of the spiritual writing angle, the dimension of listening was added. For example, the writing in the spring of 2003 the long poem 'heaven' there is a lot about the description of the divine voice description:

"(One)That will be born of love, his voice became universal on the road and in the waters chorus, wings / roundabout, covering / heaven in the spirit of God," the first patrol"...

(Seven) the master of the kingdom of heaven, the bright morning star / the root of David who speaks and is glad to speak to you!" The person who heard it should say, "come!” " Every angel should say, "come!" / the thirsty should come, and the willing will come and drink the water of life..."

In writing this first poem in the spring of 2003, 'every day' can play the 'voice' of the narrative. This is the 'divine voice' in the text of the performance of its own creation, there have been some changes, Shi Wei said: "I believe the writing is very unique, and I used completely different methods to usual, how to write everything when the Holy Spirit told my personal devotions. When someone asks me what I'm going to write about, it's hard to answer. I just smile that I'm a printer, I write everything, and see when God switches, and decide what to print." ${ }^{[8]}$ Shi Wei's writing became a creation under the guidance of the Holy Spirit.

Contemporary western academia has rediscovered the importance of hearing and listening. This is the revival of the Hebrew tradition, and the return to prominence of France's Levinas and Derrida is one of them. Listening to the transcendental sounds of Chinese literature can not only bring about changes in spiritual literature, but also return to Chinese cultural traditions and listen to the details of Chinese civilization. In the creation of 'spiritual literature', we can see the writings are to convey truth. Due to its pursuit of Tao, we see the Chinese and Western culture within it Tao. Wu Jingxiong once said, "Confucianism, Taoism and Zen are more enthusiastic in the West than in the East." As far as I know, many people in the West have returned to Christianity through the exploration of the Far Eastern religions. This is because of the mystery and moral insight in the religion of the Far East, reminding them of the endless treasure of the gospel. It is the time for Christians to assimilate the truth, the good and the beautiful of all the living traditions of human beings and to the Tao! The

\footnotetext{
${ }^{[5]}$ Yu Hong: "The Tragic Experience of Contemporary Christian Chinese -- Ding Fang Art", see Wang Zhongxin Editor: "Christian and China" (fifth series), Los Angeles: NOK-Freudenberg Foundation, 2007 edition, page 7

[6] Shi Wei: "Song of Solomon", Zhuhai Press, 2009 Edition, page 182

[7] Shi Wei: "Song of Solomon", Zhuhai Press, 2009, pp. 261-268

[8] Shi Wei: "to Manelli", the Chinese Bible Association Limited, 2014 edition, preface
} 
Tao inspires no earthly man. Finally, we must remember that before we turn water into wine, we must fill the kettle with water." ${ }^{[9]} \mathrm{Wu}$ Jingxiong referring to the "water into wine, to fill the kettle with water, is borrowed from the New Testament" John recorded in Jesus Garner for the wedding to turn water into wine works, to meet Chinese culture and metaphors of Biblical culture. Wu Jingxiong believes that the first thing is to return to China the cultural traditions of Confucianism and Zen, 'filled the kettle' as the premise, and then by the Christian culture, to become 'wine', in order to update and improve Chinese culture. In the return encounter in two kinds of traditional civilization to dialogue with Huitong deeply, in order to achieve one should follow 'DESAY' with the practical purpose has covered the light coming through, and some enlightenment are intertwined, and Chinese Qin had intertwined transcendental light, there may be a kind of beyond the Eastern or Western centrism new spiritual ecology." In the Chinese spiritual literature creation, we have seen the pursuit and Huitong of 'Tao' clues. Listening to the transcendental spiritual dimension is not only listening to Western religious traditions, but also a process of returning to the Chinese literary and cultural traditions.

In fact, spiritual literature has also spread Chinese culture in the 'reverse'. As overseas Chinese Christian writing has spread into Chinese culture, Shi Wei, work in the literary and cultural dissemination China. In the past, Shi Wei's literary works were mostly 'Chinese', and personal work experience had more "convenient" characteristics to spread Chinese contemporary literature. In addition to publishing and publishing in China, Shi Wei's poems and novels are also published in large numbers, such as the American Life Quarterly, the blue sky and the overseas campus. Shi Wei's new book, "Rebel", was published in the southern press and sold well in the United States and gained a certain reputation.

Shi Wei's literary creation with its particular way of spreading Chinese literature also played the function of 'spiritual literature'. Shi Wei edited a 'spiritual literature' series, and more than 100 selected 'spiritual literature’ writers are mostly Chinese contemporary writers. Overseas campuses assist Shi Wei's publication of spiritual literature in China; at the same time the campuses also sell the spiritual literature series to overseas Chinese communities and have a certain impact. When this 'divinity writing' by Chinese contemporary literature writers as 'spiritual literature' was introduced to the overseas Chinese community in the world. Chinese literature, and spiritual literature writing to a certain scope and extent also played the 'bridge' role in the contemporary culture exchange between China and the rest of the world, and may be in the field of literature and culture, a way and a platform for cultural communication. The campuses also set up the Chinese Christian writers and Artists Association to gather Chinese Christian writers from all over the world. Among them, Chinese contemporary writers still occupy the majority of the population. This kind of external promotion is also realizing the foreign 'listening' to Chinese contemporary literature".

Reaching down, China was forced to embark on the road of modernization, 'middle west' is gradually in the process of 'Western learning', before attention is paid to missionaries and sinologists and government organizations in the dissemination of Chinese culture to Chinese Christians in the creation of more, with relatively little attention. The identities of Shi Wei and other Chinese writers' because of cultural contact, and the cultural background with China and accepted Christianity, this is perhaps precisely because of their position 'between' a cultural situation and writing culture. In a more profound level to achieve a combination of Chinese and Western culture is a kind of 'listening', and ultimately the 'West' is implemented, these are worth further consideration.

[9] Wu Jingxiong, "China Philosophy Spirit of Joy", Taipei: Sophia Press, 1999 Edition, Page 73 
Paying attention to the important of the dialogue between Chinese and Christian culture Mr. Pan Zhichang said: "The big Chinese song Wang Anshi said:" Wednesday on behalf of the occasion, the sage in Confucianism, the sage in the Buddha. ". This sentence speaks of the mystery Chinese ideas concise and comprehensive, progressive conversion. But to add that saints are more Christian than they are in today's world." ${ }^{[10]}$ The dialogue between Chinese and Christian culture is the destiny left by history to Chinese intellectuals. In modern times, there have been a lot of Chinese immigrant writers walking on the road of this dialogue, the Chinese cultural identity of writers in a western environment, under the influence of Christian culture, the part of them with a Chinese cultural background but accepted Christian beliefs, they are "between" the cultural situation of them the literary and cultural books written "the forefront of civilization dialogue" works, their works itself is a blend of Chinese and Western culture traces, these Chinese writers will bring the dialogue and exchanges between Chinese and Western cultures to enlightenment.

\section{References}

[1] Don Lin: Invisible Signs: Modern Chinese poetry and Christianity. Chinese Social Sciences Press, 2004

[2] Edited by Yang Jianlong: Soul Rescue and Spiritual Literature, Singapore Youth Press, 2009 Edition

[3] Liu Guangyao, editor: Theological Poetics: Fourteen poets' talk, Kyushu press, 2012

[4] Wang: The Cultural Orientation of Chinese literature. Huacheng publishing house, 2014 press

[5] Wu Yiyi, Chen Hanping: Search For Identity: A Study of New Immigrant Literature in the Global Perspective. Chinese Social Sciences Press, 2012 Edition

[6] Tan Guilin, Gong Min's Law: Contemporary Chinese literature and Religious culture, Yuelu Academy, 2006 Edition

[7] Yang Huilin: Meaning - the Public Nature of Contemporary Theology. Peking University Press, 2013 Edition

\footnotetext{
${ }^{[10]}$ Pan Zhichang: The Starry Sky Above the Head: Aesthetics and Ultimate Concern. Guilin: Guangxi Normal University press, 2016 edition, seventy-fourth
} 